\title{
Die Bybelse Basis vir Menseregte
}

\author{
H G v d Westhuizen
}

\section{Inleiding}

Ons het 'n koersgewende artikel in die kritiek teen Moltmann se teologiese basis vir menseregte in dr C J Mans se bydrae in die H.T.S. 29, 4, waarvan die opsomming ook in Engels vertaal aan die World Alliance of Reformed Churches beskikbaar gestel was.

Tog is daar ineengestrengel met die duistere arms van hierdie grondslag van menseregte ook ligarms wat teologiese drakrag het. Die aanduiding van hierdie positiewe teologiese tendense by Moltmann ontbreek nog grootliks. Verder is aan ons nog nie juis 'n substituut aangebied om die koers aan te dui in ' $n$ meer Bybelse beskouing oor menseregte nie.

\section{Beoordeling van die teologiese koersbaan vir menseregte}

Om enkele waarderende punte aan te stip, wil ons die teologiese riglyne (Theological Guidelines) van die Wêreldbond van Hervormde Kerke ondersoek. Hierdie koersbaan is op 18.02.1976 in London opgestel, hoofsaaklik onder invloed van Moltmann.

(a) God stel vereistes aan menswees. Menseregte is nie gebaseer in die menslike op sigself nie, maar in wat God van die mens vir die mensdom verwag. Soos later aangedui, meen ek 'n mens kan op hierdie koersbaan 'n teologiese basis vir Bybelse menseregte vind

(b) Menslike lewe in sy geheel vereis drie basiese ewewigtighede

(i) Gelykwaardigheid (equal dignity) en interafhanklikheid van man en vrou. Die bedoeling is sekerlik goed om byvoorbeeld die vrou nie as mindere mens te beskou nie. Tog word hier m.i. reeds ' $n$ basiese fout begaan. "Gelykwaardigheid" moet hier liewers vervang word met "wesengelykheid". Wat wese betref is man en vrou gelyk, maar die Bybel ken 'n status-ongelykheid tussen man en vrou. Die waarde van 'n vrou verskil van dié van ' $n$ man in ooreenstemming met haar vroulike status. ' $n$ Deugsame vrou se waarde is ver bo korale - nogtans is sy geskape as hulp wat by die man aanpas (Gen 2:18; I Kor 11:7-9; I Tim 2:11-15; Ef 5:22-33; I Petr 3:1-7).

(ii) Gelykgeldigheid (equal validity) en interafhanklikheid van persoonsregte en samelewingsregte. Die bedoeling hiervan is sekerlik ook goed. Maar dit kan nie ongekwalifiseerd as algemene stelling sonder meer geponeer word nie. Twee of meer persone in dieselfde situasie (beskawing, status, ens.) het sekerlik'n gelykgeldige reg. Maar waar jy met konings: onderdane; geleerd: ongeleerd; beskaafd: onbeskaafd; fluks: lui; gesond: krank; jonk: oud; een volk: ander volk, 
ens. te doen kry, moet daar onderskei word waar dit op aankom. Elke dissipline het sy regte na eie aard.

(iii) Gelykwaardigheid en interafhanklikheid van die huidige menslike geslag en die toekomstige geslagte in die bestuurskap van die skepping. Hier vind ons ook pragtig die gedagte van verantwoordelikheid wat óns dra met betrekking tot toekomstige geslagte. Maar ook hier kan ons eerder van 'n wesensgelykheid tussen die huidige menslike geslag en die toekomstige spreek, want die waarde van geslagte, volkere en kulture verskil onderling. Die een waardeer die skepping hoër as die ander en handel daarmee dienooreenkomstig (Gen 2:15; 3:23).

Verder stel die teologiese koersbaan vir menseregte dat op grond van die verbondsverhouding tot God, van ons bogenoemde verbondsverantwoordelikhede vereis word in die bestuurskap van die skepping. Die werksverbond en die skepping na die beeld van God vorm hier die pilare vir die menslike roeping. Maar tot sover toe is dan nog geen woord oor sonde en genadeverbond gespreek nie! Daarom ontbreek in die drie ewewigtighede hierbo genoem die nodige onderskeidinge, soos aangedui. Die gelykgeldigheid en interafhanklikheid van my regte en die regte van my buurman is dus ook ' $n$ vrysinnige gelykheid. Wat word onder buurman verstaan? Hy wat langs my woon en miskien my vader is op wie se grond en goedheid ek teer? Weereens is die bedoeling goed, mits daar geen verskil sou bestaan in status en geen maatskaplike korrupsie en sonde variëteite nie.

Dit is verblydend om in hierdie koersbaan te verneem van die gelyke betekenis en interafhanklikheid van menseregte en mensepligte! Dieselfde Here wat die voorreg van menselewe verleen en regte daaraan verbind, lê ook verantwoordelikheid of pligte op die mens.

(c) Die Bybelse geloof waarsku ons teen die vernietigingsmagte in ons stryd vir die realisering van menseregte. Die beeld van God is verduister in ons wêreld. ... "As a result we must confess that the exercise of human rights participates fully in the anbiquity of human life and can be destructive as well as creative, demonic as well as holy. Being human is being threatened by Sin, Satan and Death ..."

Dit is goed om hierdie waarskuwing ook te beluister. Maar ons beluister nie hier die totale sondigheid van alle menslike versinsels nie. Die totaliteit van die sonde ontbreek. Dat die hele wêreld in die mag van die sonde lê en dat ons van nature, dit wil sê altyd en volledig sondaar is, veronderstel 'n volgende alomvattende inkomplementariteit (wat ontbreek): die ongelykheid van die mensdom se diepe sondigheid en die wydsheid van God se uitverkiesende genade in Jesus Christus.

(d) Die belydenis van Jesus Christus se bevrydende krag deur die kerk se bediening van versoening en genade, is mooi-klinkend maar half van koers af. Die inhoud van die versoening en genade word wel vasge- 
bind aan die "witness to the liberating power of Christ's cross and resurrection ..." Maar die inhoud word onmiddellik verwurg deur die kerk se taak te maak tot ' $n$ "struggle for human rights where, there is no way to avoid conflict between different groups, particularly between the rich and powerful and the poor and powerless." Teenoor die apostolaat en die pastoraat word die diakonaat van die kerk met'n swaardmag uitgebrei en verhef tot die wese van die kerk. "The Church, Christian congregations, and ecumenical organisations have the clear task and duty of identifying, promoting and realizing human rights". In hierdie diakoniese stryd, soms blykbaar drakoniese rewolusie, moet die kerk glo bly optree in die verwagting van die "final goal ... the reconciled community within the one family of God." Ook hier verneem ons niks daarvan dat nie alle mense in Christus gered is soos almal in Adam verdoem is nie (Die Heidelbergse Kategismus Sondag VII). Die geloof in Jesus Christus speel geen kardinale rol nie.

\section{Teologiese bakens vir menseregte}

(i) Die skepping van die mens is na die beeld van God.

"Uitgaande van die geloof dus dat hierdie mense (Boesmans, Hottentotte, Bantoes) ook medeskepsels is en daarom ook kinders van God kan wees, het die blanke Christen (in S.A.) hoe langer hoe sterker tot die oortuiging gekom, dat hy 'n roeping van God het teenoor die primitiewe inboorlinge ..." (H P Wolmarans, Menswaardigheid en menslike regte na aanleiding van die Skrif, H.T.S. Desember 1962, bl 86). Ons aanvaar saam met Moltmann dat die korrekte beskouing van menseregte moet terug gaan na die skepping van die mens na die beeld van God (imago Deï). Maar presies hier moet die regte koers na die volgende baken gekies word. Moltmann wys tereg die oud-oosterse opvatting af: "The shadow of God is the prince and the shadow of the prince is the people." Dat God die mens en daarmee bedoelende elke mens, nie net die koning nie, na die beeld van God geskape het, is waar. Maar elke mens is nie meer beelddraer van God nie. Die sondeval het dit vernietig. (H P Wolmarans, God en Mens, bl 192.

(ii) Die beeld van God is die mens se kindskap van God, nie sy skepselskap van God nie.

Hierdie kindskap moes die mens gehoorsaam verwerklik maar hy het dit vernietig met die sondeval. "Met die verdieping wat die begrip beeld van God in die Nuwe Testament ondergaan, skyn die uitdrukking kind van God die mees adekwate interpretasie van die $\mathrm{Ou}$ Testamentiese beeld van God te wees" (E S Mulder, "Die Mens na die 
Beeld van God in die Ou Testament, H.T.S. Nov. 1959, bl. 121). Die mensereg is dus vanweë die imago Deĩ "alleen te sien in (die mens se) verhouding tot God as kind van God." (H P Wolmarans, H.T.S., a.w., bl. 89). Jy moet eers kind van die Here Jesus word (Joh 21:5) om kind van God te wees (Joh 1:12; Luk 20:36; Gal 3:36; . 4:5). Jesus is die ware mens (Joh 19:5; I Kor 15:45).

\section{(iii) Menswaardigheid lê in die kindskap van God.}

Menseregte wat voortkom uit menswaardigheid vanweë die mens se kindskap van God (Vgl. H G v d Westhuizen, Vertrou op God, Hoofstuk 7, Kindskap), is inklusief nie eksklusief nie. Omdat God met sy bedoeling in die skepping van die mens aan die mens ware menslikheid wil verleen - naamlik kindskap van God, daarom stel God se bedoeling eise aan my as gelowige om enige mens as ' $n$ potensiële gelowige of kind van God te sien. Uit hoofde hiervan is die mees fundamentele mensereg in die praktyk dat die evangelie aan hom verkondig moet word. So vind ons in die Bybelse beskouing van menseregte ' $n$ fundering van die sending.

\section{(iv) Menseregte is dus gegrond in God se reg vir die mense}

Dis 'n genadereg wat alleen gerealiseer word in die genadeverbondnie in die skeppings- of werkverbond nie. Die wit lig van God se reddende genade in Jesus Christus word soos deur 'n prisma deur die kerklike roeping opgebreek in die veelkleurigheid en veelsydigheid van menseregte. Omdat vanweë die sonde die mens velerlei te ly het, het God deur sy Woord bepaal dat daar'n verskeidenheid van praktiese reëlings moet wees om sy kinders of moontlik toekomstige kinders te versorg. Die mees opmerklike in verband met hierdie verskeidenheid van menseregte, is dat dit deur God gegee is (Spr 29:26). Dit kom nie uit die mens humanisties voort nie. Soos God die mens na sy beeld geskape het (Gen 1:26; I Kor 11:7), het die mens dus as kind van God ván God menseregte. Hierdie mensregte moet uitgeoefen word tot eer van God, in gehoorsaamheid aan God (Gen 1:28; 2:15). Waar mense hulle regte aanmatig wat in stryd is met God se reg vir die mens, is hulle op die weg van eiereg wat sy oorsprong in die sondeval het (Gen 3:5,6). die vrye reg om te doen wat die mens(dom) wil, is sondige humanisme en uit sonde gebore liberalisme.

Daar is nie twee stelle menseregte of een stel net vir sommige mense, die gelowiges nie. Ons kan nie sê die gelowige, die kind van God, die beelddraer van God, het menseregte en die ander nie! Net soos ' $n$ ongebore baba in sy onwetenheid regte het en die tot sterwens bewustelose mens ook, so het ook die onkundiges of ongelowiges. Net maar hulle weet nie reg daarvan nie. Die ongelowige 
weet nie waar sy reg vandaan kom, wat dit altyd inhou, wat dit van hom verwag en wat dit beteken nie. Daarom is die gelowige se sendingroeping des te dringender. Die gelowige weet ook nie of die ongelowige van vandag, môre dalk'n kind van die Here kan wees nie.

Die feit van ons lewe is ' $n$ voorreg van God aan ons gegun. Ons begripvolle lewe is 'n genade van God (I Petr 3:7). Daarom moet ons met menseregte groter erns maak, ómdat dit van God kom, as wat ons daarmee sou maak as dit maar net van mense sou kom. Omdat die lewe vir ons Christus is (Filip 1:21), is die Christelike lewe, bo alles, ook ernstig.

\section{(v) Elke mens het 'n geboortereg van God}

Omdat God die mens bestem om sy kind te moet word, kan ouers nie aborsie pleeg na willekeur nie. God wil beskik oor die geboorte (Ps 139:16; Jer 1:5; Gal 1:15).

\section{(vi) Elke mens het' $n$ sterwensreg van God}

Aktiewe euthanasie, moorddadige optredes, aggressiewe oorlogsvoering, gewelddadige rewolusie met gepaardgaande ontydige lewensverlies, is omverwerping van God se sterwensreg vir die mens. Ook hierdie sterwensreg verleen nie willekeur aan die betrokke mens self nie, net soos geen Bybelse mensereg liberalisties is nie. Mensereg is Godsreg vir die mens (Eks 20:13; Gen 9:6).

\section{(vii) Elke mens het 'n lewensreg van God}

(a) Volkshuishoudinge mag beskerm word. God wil volkere. Elke volk het 'n Godgegewe reg van bestaan. Die kultuuropdrag om die skepping te bewerk en te bewaar en die aarde te vul, was vóór die sondeval. Met "vul" (Gen 1:28) word vóór die sondeval sekerlik al nasies bedoel, veral as ons dit lees in samehang met Handelinge 17:26: "En Hy het uit een mens al die nasies van die mensdom gemaak om oor die hele aarde te woon terwyl Hy vooraf bepaal het hoelank hulle sal bestaan en waar hulle sal woon." Lees ook Deuteronomium 32:8. God stel historiese en geografiese grense aan nasies. Dit meen God skenk die nasionale entiteit. "En dat God self dit bewerk het met die spraakverwarring by die toring van Babel, was nie 'n goddelike straf vir die hoogmoed van die aardbewoners nie, maar 'n openbaring van God se genade" (H P Wolmarans, H.T.S., a w, bl. 88). Owerhede het regte van God ontvang (I Sam 10:25; Matt 22:21; Rom 13:4; vgl C J Mans, Die Owerheid in die N.T. en by die Reformatore, H.T.S. Des. 1962).

Wat ons volk betref, bestaan ons nasionale entiteit (buiten die volksbodem) uit ons Christenskap, blankeskap en Afrikanerskap 
(H G v d Westhuizen, Vertrou op God, bl 95v). Ons het die reg en plig om dit, inagnemende God se ander ter saaklike regte, te bewaar. Die Heidelbergse Kategismus sê in Sondag 40 na aanleiding van die sesde gebod: "(dat ek) ook myself nie mag wond of moedswillig in enige gevaar begewe nie." As ons verstand (waarmee ons God ook moet liefhê, Deut 6:5; Matt 22:37) vir ons sê dat sekere optredes volkselfmoord beteken, moet ons daardie optredes teengaan. Enige verstandige gelowige, van watter kleur of volk ookal, moet op grond van historiese en huidige gegewens konkludeer dat ons volk in gevaar verkeer om sy identiteit te verloor indien alle apartheid opgehef word.

'Tussen 1786 en 1793 is daar in die Kaapstadse gemeente ruim 180 kinders gedoop by wie, in sombere herhaling, elke keer aangeteken staan: 'in onegt', en in byna alle gevalle word die moeder aangedui as "van de caab' - kinders van inboorlingmoeders en blanke vaders." (Dr E P J Kleynhans, Ons Kerklike Verhoudinge in Kerkhistories Kerkregtelike Perspektief gesien, Ned. Geref. Teol. Tydskrif, September 1977 , bl 302). Juis omdat dít die historiese les is, en omdat daar meer as sesvoudig méér gekleurd as blank in ons land is, en omdat dit dwarsoor die wêreld vandag 'n strewe is om te vermeng, is ons volk geregverdig om as volk maatreëls te tref vir sy eie veiligheid ( $\mathrm{H} \mathrm{G} \mathrm{v} \mathrm{d}$ Westhuizen, Vertrou op God, bl 11v).

Die Bybel bied nie alleen lig waarin gewone owerspel of egbreuk veroordeel word nie, maar ook aanduiding dat daar spesifieke seksuele verbintenisse is wat binne en buite ' $n$ huwelik spesiaal verbode is (Lev 18:6-18; Hand 15:20, 29; I Kor 5:1). Gemengde huwelike, d.w.s. huwelike tussen burgers van verskillende volke, is assodanig nie Bybels veroordeel nie. Mits die huwelik kan voldoen aan die paslikheidseise (Gen 2:18). Maar ons sien in die Bybel wel dat as gemengde huwelike die identiteit van 'n volk bedreig, dit te sterkste afgekeur word (Esra 9; Neh 13:25). Indien huwelike tussen ons volk en Hollanders, en Engelse, en Franse ens. vir ons volksidentiteit geen gevaar inhou nie, is derglike huwelike normaal. Maar huwelike tussen ons en gekleurde rasse is assodanig reeds identiteitsverwoestend; nog meer só in bogenoemde omstandighede. Daarom is die Wet op Gemengde Huwelike en die Ontugwet geregverdig in ons land. Die handhawing daarvan is verantwoordelikheid. Dit raak niemand nie behalwe die oortreders. Die toepassing van die wet moet ook regverdig en verantwoordelik geskied.

Alhoewel bogenoemde wet van ons kant gesien, ons volk op die oog het, het dit ook ' $n$ ander kant. Daarom dat in die Transkei omstreeks 1890 of 1895 'n spesiale petisie aan die ou Kaapse Parlement gerig is om seksuele verkeer tussen blankes en Pondos te verbied lank voordat die blankes die Ontugwet geproklameer het (Prof Murray, Die Transvaler, 11 Oktober 1971).

Die Godsreg vir volke word uitgebrei tot sy ware diepte wanneer 
Jesus die direkte opdrag gee om "dissipels van al die nasies" te maak (Matt 28:19). Daarna sal die duiwel nie meer kan sê dat al die koninkryke van die wêreld aan hom behoort nie (Matt 4:8). God gee self die krag (Hand 1:8) waarin die kerk die evangelie aan alle nasies moet verkondig (Hand 2:6). Die Godsreg vir volke strek tot in die nuwe Jerusalem: "En die nasies van die wat gered word, sal in die lig daarvan (van die Lam wat die lamp is) wandel, en die konings van die aarde bring hulle heerlikheid en eer daarin" (Openb 21:24).

(b) Eienaars het Godgegewe regte om hulle eiendomme te besit en te beskerm (Ef 4:28; Eks 22:1, 7). Die hele erfgedagte veronderstel privaatbesit (Deut 21:17; Spr 19:14; Luk 15:12), en so ook die dankoffergedagte (Lev 7:11v.; 27:30v; Deut 14:22v; Spr 3:9, 10; 13:11; 10:5; I Kor 16:2; II Kor 9:7; ens.) Berkoff sê na aanleiding van Eksodus 23:10ev.; Levitikus 25 en Deuteronomium 15:1-18, "dat de mens het bezit van God leent ..." (Christelijk Geloof, bl 523).

(c) Huweliksliede het huweliksregte volgens Bybel (Eks 21:9; I Kor 7:14; e a; huweliksformulier, leviraatshuwelike; ens.). Selfs primitiewe samelewings en alle beskawings het sy huweliksregte. Ook huweliksregte, soos ander regte, lê die individu se vryheid aan bande. Menseregte is dus nooit'n ongekwalifiseerde vrysinnige vryheid nie.

(d) Vreemdelinge was mense wat vanweë oorlog, hongersnood, plae en ander probleme beskerming of ' $n$ heenkome soek op' $n$ ander plek as sy gewoon-regtelike lokaliteit. Sy siviele regte soos ten opsigte van byvoorbeeld eiendomme, huwelik, kultuur, oorlog, regsadministrasie is ingekort op die plek van sy vreemdelingskap. Tog het God aan hom 'n vreemdelingsreg verleen: "(Dit is God wat) die vreemdeling liefhet sodat Hy hom brood en klere gee. Daarom moet julle die vreemdeling liefhê, want julle was vreemdelinge in Egipteland" (Deut 10:18; Matt 25:35; vergelyk Koehler-Baumgartner, s v gēr, xenoi).

Selfs hierdie vreemdelingsreg is geen ongekwalifiseerde mensereg waarop byvoorbeeld in ons land aan elke die reg verleen word tot ' $n$ huwelik met wie hy wil, woning en werk waar en wanneer hy wil nie. Daarby moet ons onthou dat "diskriminasie in die sin van veragting en verguising van ander minderbevoorregte skepsels van God, 'n skandvlek (is) op die lewe van die nasaat van die Hollandse W'atergeus en die Franse Hugenoot en die Vrystaatse of Transvaalse Voortrekker en (dit) is voor God en die Christelike gewete nie te verantwoord nie. Dis'n euwel en openbare sonde wat uitgeroei behoort te word." (H P Wolmarans, H.T.S., a w, bl. 89).

Die vreemdeling in 'n volkshuishouding, soos byvoorbeeld in die Afrikanervolkshuishouding, moet ook weet van dankbaarheid en menslike verantwoordelikhede. "Dat dit hier (in S.A.) nooit (in die geskiedenis) uitgeloop het op die uitdelging van die ander rasse nie, soos wat elders in die wêreld wel gebeur het, is alleen te danke aan 
die Blanke nedersetters se geloof aan God as die Skepper-heer van alle mense ... As daar mense vandag in Suid-Afrika is, wat die Here God moet loof en dank, daarvoor dat dit geloofshelde en geloofsheldinne was, wat hier die grondslag kom lê het van die westerse beskawing, met die Christelike kerk in Suid-Afrika, dan is dit die Bantoe en die Kleurlinge." (H P Wolmarans, H.T.S., $a$ w, bl. 87).

Vreemdelinge het in die Bybel nie aanspraak op gelyke behandeling as die volkseie nie - selfs nie wat hulle begraafplaas betref nie (Matt 27:7).

(e) Weduwees en wese. Hierdie mense het volgens die Bybel se tye nie geërf soos ons praktyk vandag is nie (II Sam 12:8). Die weduwees het geen regsvoorregte gehad nie (Joh 8:1-11). Weduwees was verdruk (Ps 146:7 in die beryming; Job 22:9; 24:3, 9; Ps 94:6). In die Ou Testament is ryk weduwees skaars. In die Nuwe Testament ook. By wyse van uitsondering vind ons in Handelinge 12:12 Maria wat moontlik 'n ryk weduwee was. Buite Palestyna was daar waarskynlik meerdere ryk weduwees, byvoorbeeld Lydia die purperverkoopster (Hand 16:14).

Wese was swerwelinge wie se bedel-armpie soms vergruis is (Job 22:9; Ps 109:9-10; Spr 23:10; Job 6:27).

Nogtans het God 'n reg aan hierdie mense verleen (Deut 24:17) soos oes-reste wat hulle mag insamel (Deut 10:18; Ps 10:18; Lev 23:22; Deut 24:19; Eks 23:11; vgl ook die lossersreg).

(f) Ander noodlydendes. Vanweë die sonde is die wêreld vol van noodlydendes. Daar is nog onderdruktes, verswakte oues van dae, armes, siekes, ens. (Spr 31:9).

Slawe moes by Israel na 6 jaar vrykom (Job 31:13, Eks 21:2; Deut 15:12). Maatskaplike en politieke onderdruktes moet van onderdrukking bevry word. Dit beteken egter nie dat sonder onderskeid volksvreemdes volksvoorregte mag geniet nie. Reg en billikheid is die wagwoord (Kol 4:1).

Oues van dae kan nie maar geëlimineer word nie. Hulle het inteendeel 'n reg van hoogagting (Spr 23:22; Filêmon 9).

Ons sal die armes altyd onder ons hê (Matt 26:11). Daarom verleen God sekere regte aan hulle - nie waarop hulle soseer aanspraak kan maak nie, maar waaraan die gelowige van die Ou Testament moes voldoen, en mutatis mutandis ook ons (Eks 23:6; Spr 29:7; Job 29:16; Jes $5: 8 ;$ Ps $82: 3 ; 140: 13$ ). Die eie volksgenoot moes lenings ontvang en selfs na sewe jaar kwytskelding van skuld (Deut 15:4, 7-11; Neh 5:6-11). Ons bemerk telkens ' $n$ diskriminasie ten gunste van die volksgenoot in die betrokke volkshuishouding, wat natuurlik vanselfsprekend en korrek is. Ook 'n renteverbod is ingestel (Eks 22:25; Deut 23:19).

Ook die profete het opgekom vir die menseregte van die armes vanweë God se Woord (Amos, Jes 1:23; 10:2; 29:20; Miga 3:9, 11; Sef 3:3; Jer 22:16; Eseg 22). 
Die Nuwe Testament toon Jesus as geneser, voeder, helper. So het Hy simptomatiese dade verrig van sy groot daad aan die kruis: die verlossing uiteindelik uit alle nood. Die vroeë Christene het die Joodse gebruik om Vrydae liefdesmaaltye vir die armes te hou, voortgesit in kombinasie met die nagmaal, waarvan ons nagmaalstafelgeld vandag nog ' $n$ oorblyfsel is. Die amp van die diakens is spesifiek vir die versorging van noodlydendes. Hulle moet nie net materiële hulp nie maar ook emosionele bystand verleen (Rom 12:15; Jak 1:27). Elke gelowige moet ook priesterlik, soos die barmhartige Samaritaan, sy naaste in nood te hulp snel (Rom 12:1; Luk 10:30-37).

Die diakonaat gegrond op die mensereg wat God aan die noodlydende verleen, het ' $n$ hoogbloei beleef tot aan die begin van die 4 de eeu nC. "Reeds onder het Romeinse rijk viel de christenheid door deze kenmerken buiten het gedragspatroon ... In afwijking van het grieks-romeinse mensbeeld worden dienst, nederigheid en zelf-verloochening tot dominerende waarden." (H Berkhof, Christelijk Geloof, bl. 531). Nadat die Christelike godsdiens staatsgodsdiens geword het, het die kerk sy versorgende diakonaat al meer oorgelaat aan die staat. Toe het alle staatsburgers, nie net gelowige kerkmense nie, dit as ' $n$ reg beskou om eners as alle ander mense behandel te word.

Omdat Moltmann die genadeverbond met sy volle Bybelse inhoud grootliks uit die oog verloor, het hy nie die hoogste agting vir soewereiniteit in eie kring nie. Hierdie regte is nie van die eie kring (owerheid, kerk, gesin, ens.) nie maar deur God verleen in daardie kring. En hierdie reg mag nie holisties omver gewerp word deur gehoorsamer te wees aan die mens(dom) as aan God nie (Hand 5:29). Moltmann sê inderdaad dat internationale-solidariteit bo eiekring-lojaliteit staan: "International solidarity . . . has . . . because of the rights of humanity, a precedence over loyalty to one's own people, to one's own class, race, or nation" (bls 12).

\section{Samevatting}

Ons hoef nie 'n teologie van menseregte te probeer ontwerp nie. Ons moet slegs maar begripvol, daadvol en kerklik ons naaste liefhê soos ons self. Om daarvoor teologiese bakens te vind, moet ons gaan na die tweede tafel van die dekaloog. Menseregte en mensepligte in verhouding teenoor mekaar, is onverbeterlik geponeer in die vyfde tot die tiende gebod. Wie aan hierdie menseregte van sy naaste beantwoord, kan teologies nie anders as om aan God se reg vir hulle te beantwoord nie en hierdie Godsreg ook te verkondig aan die naaste. My medemens se grootste reg is om van my, van God te hoor. Om ware mens te word is om kind van die Here Jesus Christus te word. $\mathrm{Hy}$ is die beeld van God (II Kor 4:4; Kol 1:15).

Mensereg kan nie gebaseer word op die mondigheid van die mens nie, maar in God se wil met die mens. 